Огляди літератури, оригінальні дослідження, погляд на проблему

УДК 612.015.3:611.018.4-02:616.314.18-002.4-06:616.441-008.61/64]-092.9

DOI 10.11603/1811-2471.2017.v0.i4.8379

\title{
ПОКАЗНИКИ КІСТКОВОГО МЕТАБОЛІЗМУ У ЩУРІВ З ПАРОДОНТИТОМ НА ФОНІ ГІПЕР- ТА ГІПОТИРЕОЗУ
}

\author{
๑В. В. Щерба, І. Я. Криницька, В. Р. Мачоган, М. М. Корда
}

ДВНЗ «Тернопільський державний медичний університет імені І. Я. Горбачевського МОз України»

РЕзЮМЕ. В Україні за останні п' ять років кількість хворих з дисфункцією щитоподібної залози збільшилася у 5 разів. Зміни діяльності щитоподібної залози неминуче позначаються на різних системах організму, у тому числі й на функції і морфології органів та тканин порожнини рота.

Метою дослідження було вивчити показники кісткового метаболізму у щурів з пародонтитом без супутньої патології і на фоні гіпер- та гіпотиреозу.

Матеріал і методи. Досліди проведено на 48 безпородних статевозрілих білих щурах-самцях, які були поділені на чотири групи: контрольна, група з пародонтитом, група з пародонтитом на тлі гіпертиреозу, група 3 пародонтитом на тлі гіпотиреозу.

Результати. Експериментальний пародонтит супроводжується порушеннями метаболізму кісткової тканини внаслідок посилення як процесів резорбції, так і процесів кісткоутворення. Пародонтит на тлі гіпертиреозу характеризується більш вираженими порушеннями кісткового метаболізму за рахунок одночасного підвищення процесів резорбції та кісткоутворення. Пародонтит на тлі гіпотиреозу супроводжується гальмуванням процесів резорбції кісткової тканини та менш вираженим кісткоутворенням.

КЛючОВІ СЛОВА: пародонтит; тиреоїдні гормони; кістковий метаболізм.

Зв' язок роботи з науковими програмами, планами, темами. Робота є складовою частиною науково-дослідної теми «Біохімічні механізми порушень метаболізму за умов надходження до організму токсикантів різного ґенезу»; № держ. реєстрації 0116 U003353.

Вступ. Ендокринна патологія сьогодні посідає третє місце серед усіх захворювань. У структурі ендокринних хвороб поширеність патології щитоподібної залози $(46,7 \%)$ вже перевищує поширеність цукрового діабету $(31,9 \%)$ і тенденція до її зниження відсутня [1]. В Україні за останні 5 років кількість хворих з дисфункцією щитоподібної залози збільшилася у 5 разів. На диспансерному обліку перебувають 3,5 млн осі6, 70 \% населення страждають внаслідок дефіциту йоду [2]. Зміни діяльності щитоподібної залози неминуче позначаються на різних системах організму, у тому числі й на функції та морфології органів і тканин порожнини рота [3].

Кісткова тканина $\epsilon$ динамічною структурою, що постійно оновлюється та перебуває під контролем великої кількості системних і місцевих факторів, серед яких важливу роль відіграють саме гормони щитоподібної залози. Сучасні дослідження довели дуалізм ефектів тиреоїдних гормонів на кістковий метаболізм. 3 одного боку, трийодтиронін шляхом прямого впливу на остеобласти і хондроцити стимулює остеогенез. 3 iншого боку, через опосередковані механізми впливу на остеокласти трийодтиронін ініціює резорбцію кісткової тканини [4]. Дія тиреоїдних гормонів опосередковується рецепторами гормонів щитоподібної залози (TR), котрі кодуються генами THRA і THRB [5]. Розрізняють декілька видів тиреоїдних рецепторів: TRa1, TRa2, TRß1 та TRß2 [6]. Вони локалізуються не лише на тиреоцитах, але й на більшості людських клітин. Лише TRß2 пов'язаний з гіпоталамусом і гіпофізом, де гальмує секрецію ТРГ і ТТГ. Експресія рецепторів у кістці безпосередньо свідчить, що ця тканина знаходиться під впливом тиреоїдних гормонів. Остеобласти та хондроцити мають на своїй поверхні обидва види рецепторів - TRa i TR $\beta$, але чисельність TRa1 рецепторів у 10 разів перевищує кількість TRß1 рецепторів [6]. TRa1 вважають основним функціональним медіатором впливу трийодтироніну на скелет [7]. Біологічна роль TRa2 залишається невідомою. $€$ дані, що трийодтиронін бере участь у регуляції хондрогенезу та кісткової мінералізації. Він стимулює IL-6 та IL-8, посилює ефекти IL-1 та IL-6, підвищує синтез остеокальцину, колагену типу I, збільшує проліферацію, диференціювання та апоптоз остеобластів [8]. Під час формування кістки Т3 стимулює проліферацію, диференціювання та апоптоз остеобластів і збільшує експресію остеокальцину, колагену типу 1 , лужної фосфатази, металопротеїнів, IGF-1 та його рецептора (IGF-1R). Згодом, під час резорбції кістки, Т3 збільшує експресію важливих факторів диференціювання остеокластів, таких як інтерлейкін-6 і простагландин Е2. Простагландини, особливо PGE2, є потужними мультифункціональними регуляторами кісткового метаболізму. PGE2 зумовлює морфологічні зміни у остеобластах і остеокластах через збільшення внутрішньоклітинного рівня циклічного аденозинмонофосфату [9]. 
Огляди літератури, оригінальні дослідження, погляд на проблему

Крім того, Т діє синергічно з остеокластогенними гормонами, такими як паратиреоїдний гормон і вітамін Д. Також було продемонстровано, що $\mathrm{T}_{3}$ збільшує експресію мРНК ліганда рецепторного активатора ядерного фактора-к $\beta$ (RANKL) в остеобластах, що активує RANK, присутній у попередниках остеокластів [10].

І. М. Піксін та співавтори стверджують, що тироксин має набагато меншу спорідненість до рецепторів тиреоїдних гормонів і вплив на клітини кісткового метаболізму [11]. За іншими даними, Т4 має виражену резорбтивну дію. Він може прямо впливати на кісткове ремоделювання, пришвидшує остеокластичну активність, стимулюючи виділення простагландинів [12].

Аналогічно, експресія ТTГ-рецепторів (TSHR) була продемонстрована в остеобластах та остеокластах, що свідчить про те, що ТТГ може мати прямий вплив на ці клітини [6]. Деякі автори заявляють, що ТТГ відіграє важливу роль у метаболізмі кісткової тканини, яка не залежить від дій тиреоїдних гормонів [10]. Інші наукові дані свідчать про те, що ТТГ $\epsilon$ негативним регулятором «кісткового обороту». Його пряма дія на клітини кісткової тканини призводить до підвищення ремоделювання кісток та остеопорозу [13].

Отже, незважаючи на велику кількість досліджень, молекулярні механізми впливу тиреоїдних гормонів на метаболізм вивчені не повністю. Особливу зацікавленість викликає вплив тироксину та трийодтироніну на метаболізм тканин пародонта за умови генералізованого пародонтиту.

Мета дослідження - вивчити показники кісткового метаболізму у щурів з пародонтитом без супутньої патології і на фоні гіпер- та гіпотиреозу.

Матеріал і методи дослідження. Досліди проведено на 48 безпородних статевозрілих білих щурах-самцях масою 180-200 г, яких утримували на стандартному раціоні віварію.

Піддослідних тварин було поділено на групи: I-контрольні тварини, яким вводили внутрішньошлунково 1 \% розчин крохмалю (n=12); II - тварини з моделлю пародонтиту. Щурам цієї групи впродовж 2 тижнів через день вводили в тканини ясен по 40 мікролітрів (1 мг/мл) ліпополісахариду (ЛПС) E. Coli ("Sigma-Aldrich», США») ( $n=12)$ [14]; III щури з пародонтитом на фоні гіпертиреозу. Для моделювання експериментальної гіперфункції щитоподібної залози тваринам щоденно внутрішньошлунково вводили L-тироксин на 1 \% розчині крохмалю із розрахунку 10 мкг/добу на 100 г маси протягом 21 доби $(n=12)$ [15]. Починаючи з восьмої доби експерименту щурам вводили в тканини ясен ЛПС протягом 2 тижнів; IV - щури з пародонтитом на фоні гіпотиреозу. 3 метою моделювання експериментальної гіпофункції щитоподібної за- лози [15] тваринам щоденно внутрішньошлунково вводили мерказоліл на 1 \% розчині крохмалю із розрахунку 1 мг/добу на 100 г маси протягом 21 доби (n=12). Починаючи з восьмої доби експерименту щурам вводили в тканини ясен ЛПС протягом 2-х тижнів. Евтаназію щурів здійснювали шляхом кровопускання за умов тіопентал-натрієвого наркозу на 22 добу від початку досліду.

Усі маніпуляції з експериментальними тваринами проводили із дотриманням правил відповідно до «Європейської конвенції про захист хребетних тварин, що використовуються для дослідних та інших наукових цілей» [16].

Для досліджень використовували сироватку крові та гомогенат тканин пародонта, який виготовляли на трис/HCl/буфері $(\mathrm{pH} 8,0)$ з розрахунку 100 мг тканини/мл [17]. Гомогенат центрифугували впродовж 30 хв при $1500 \mathrm{~g}$ та температурі $+4{ }^{\circ} \mathrm{C}$. Після центрифугування гомогенату досліджували надосадову рідину.

Для підтвердження станів гіпер- та гіпотиреозу в сироватці крові визначали вміст вільного тироксину $\left(\mathrm{BT}_{4}\right)$, вільного трийодтироніну $\left(\mathrm{BT}_{3}\right)$ та тиреотропного гормону (ТТГ) імуноферментним методом з використанням наборів фірми «Вектор-Бест» (Росія).

Кістковий метаболізм визначали за активністю фосфатаз: лужної (ЛФ) як маркера функціонування остеобластів та кислої (КФ) як маркера інтенсифікації діяльності остеокластів. Результати виражали в мккат/л. Відповідно до методичних рекомендацій А. П. Левицького та співавторів розраховували індекс мінералізації (IM) за співвідношенням показників ЛФ та КФ [18]. Крім того, визначали концентрацію остеокальцину як біохімічного маркера формування кісткової тканини та швидкості «кісткового обороту» імуноферментним методом з використанням набору фірми «DRG» (США). Результати виражали у нг/мл.

Статистичну обробку цифрових даних здійснювали за допомогою програмного забезпечення Excel (Microsoft, США) та STATISTICA 6.0 (Statsoft, США) з використанням непараметричних методів оцінки одержаних даних. Для всіх показників розраховували значення середньої арифметичної вибірки (М), її дисперсії і помилки середньої (m). Достовірність різниці значень між незалежними кількісними величинами визначали за допомогою критерію Манна-Уїтні. Зміни вважали статистично достовірними при $р<0,05$.

Результати й обговорення. Результати наших досліджень показали, що тритижневе введення щурам L-тироксину зумовило стан гіпертиреозу, що підтверджувалося зростанням концентрації вТ ${ }_{4}$ у сироватці крові у 1,8 раза $(p<0,001)$ (табл. 1). 
Огляди літератури, оригінальні дослідження, погляд на проблему

Таблиця 1. Концентрація вільного тироксину, трийодтироніну та тиреотропного гормону у сироватці крові щурів,

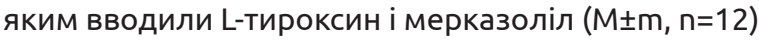

\begin{tabular}{|l|c|c|c|}
\hline \multirow{2}{*}{ Показник } & \multicolumn{2}{|c|}{ Група тварин } \\
\cline { 2 - 4 } & контроль & L-тироксин & мерказоліл \\
\hline ТТГ, мМО/л & $0,37 \pm 0,03$ & $0,16 \pm 0,02$ & $0,56 \pm 0,04$ \\
& & $\mathrm{p}_{1}<0,001$ & $\mathrm{p}_{2}<0,01$ \\
& & & $4,78 \pm 0,16$ \\
\hline вT $_{3}$ пмоль/л & $5,41 \pm 0,17$ & $\mathrm{p}_{1}<0,02$ \\
& & $\mathrm{p}_{1}<0,01$ & $\mathrm{p}_{2}<0,001$ \\
\hline вТ $_{4}$ пмоль/л & & $26,64 \pm 1,02$ & $6,65 \pm 0,44$ \\
& $15,07 \pm 0,48$ & $\mathrm{p}_{1}<0,001$ & $\mathrm{p}_{1}<0,001$ \\
& & & $\mathrm{p}_{2}<0,001$ \\
\hline
\end{tabular}

Примітки:

1. $\mathrm{p}_{1}$ - вірогідність відмінностей між контрольною і експериментальною групами;

2. $\mathrm{p}_{2}$ - вірогідність відмінностей між експериментальними групами.

Концентрація ТТГ при цьому достовірно зменшувалася у 2,3 раза. Найменших змін зазнав рівень вТ3, який також збільшився, але лише на 20,5 \% (р<0,01). Для моделювання стану гіпотиреозу використовували антитиреоїдний засіб - мерказоліл. Механізм його тиреостатичної дії зумовлений інгібуванням активності ферменту, який бере участь в утворенні тироксину і трийодтироніну - пероксидази, пригніченням процесу йодування тироніну та зниженням інкреції тироксину. Введення щурам мерказолілу протягом трьох тижнів зумовило стан гіпотиреозу, що підтверджувалося зменшенням концентрації вТ у сироватці крові у 2,3 раза ( $<<0,001)$ (табл. 1). Концентрація ТТГ при цьому достовірно зростала на 51,3 \%. Найменш виражених змін знову зазнав рівень в $T_{3}$, який зменшився на 11,6 \% (p<0,02).

Кістковий метаболізм підтримується за рахунок рівноваги процесів резорбції та формування кісткової тканини, що відображають зміни «кісткового обороту». Біохімічними маркерами кісткоутворення $\epsilon$ білки, що відображають активність остеобластів, побічні продукти синтезу колагену, матриксні білки або ензими остеобластів [19]. Ми встановили, що у тварин зі змодельованим пародонтитом активність кислої фосфатази у сироватці крові зросла на 18,1\% (р<0,01), а у гомогенаті тканин пародонта - на 34,2 \% $(p<0,001)$ відносно контрольної групи тварин (табл. 2). Що стосується активності лужної фосфатази, то цей показник у сироватці крові достовірно зменшився на 25,4 \%. При дослідженні активності ЛФ у супернатанті гомогенату тканин пародонта ми отримали протилежні дані: збільшення у 1,7 раза ( $<<0,001)$ відносно контрольної групи тварин.

У тварин з пародонтитом на фоні гіпертиреозу активність КФ у сироватці крові достовірно збільшилася у 1,5 раза, а у гомогенаті тканин пародонта - у 2,3 раза ( $p<0,001)$. При цьому актив- ність ЛФ у сироватці крові зменшилася на 8,3 \% ( $<<0,01)$. При дослідженні активності ЛФ у супернатанті гомогенату тканин пародонта ми отримали перевищення показників контрольної групи у 8,1 раза $(p<0,001)$.

У щурів з пародонтитом на фоні гіпотиреозу активність КФ у сироватці крові достовірно не змінилася відносно контрольної групи тварин, а у супернатанті гомогенату тканин пародонта - зросла на 14,1\% (р<0,05). Що стосується активності ЛФ, то цей показник достовірно зменшився на $23 \%$ у сироватці крові та збільшився у 3,4 раза $(p<0,001)$ у супернатанті гомогенату тканин пародонта.

Слід зазначити, що спрямування змін активності фосфатаз не є традиційним. Зазвичай негативні фактори зовнішнього та внутрішнього середовища зумовлюють зниження активності лужної фосфатази на тлі підвищення активності кислої фосфатази. У нашому дослідженні активність кислої фосфатази у гомогенаті тканин пародонта зростала у тварин всіх експериментальних груп, що свідчить про активацію процесу гідролізу мінеральних складових альвеолярної кістки за умови пародонтиту. При цьому активність лужної фосфатази також збільшувалася. Оскільки цей фермент $є$ маркером функціональних можливостей остеобластів, які синтезують нову кісткову тканину, то підвищення її активності при експериментальному пародонтиті можна пояснити компенсаторною реакцією кісткової тканини на підвищені процеси резорбції [20].

Мінералізуючий індекс у тварин зі змодельованим пародонтитом у сироватці крові зменшився на $36,2 \%$ ( $<0,001)$, а у гомогенаті тканин пародонта зріс на 30,3 \% (p<0,01) відносно контрольної групи тварин. У сироватці крові тварин 3 пародонтитом на фоні гіпертиреозу цей показник достовірно зменшився на $38 \%$, а у гомогенаті тканин пародонта - збільшився у 3,5 раза ( $p<0,001)$. 
Огляди літератури, оригінальні дослідження, погляд на проблему

У щурів з пародонтитом на фоні гіпотиреозу мінералізуючий індекс достовірно зменшився на
$15,4 \%$, а у гомогенаті тканин пародонта збільшився у 3,0 рази ( $<<0,001)$.

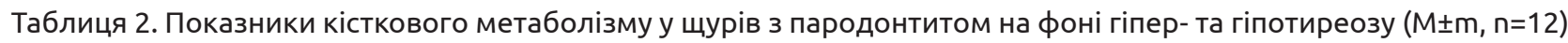

\begin{tabular}{|c|c|c|c|c|}
\hline \multirow[b]{2}{*}{ Показник } & \multicolumn{4}{|c|}{ Група тварин } \\
\hline & контроль & пародонтит & $\begin{array}{c}\text { пародонтит } \\
\text { на тлі гіпертиреозу }\end{array}$ & $\begin{array}{c}\text { пародонтит } \\
\text { на тлі гіпотиреозу }\end{array}$ \\
\hline \multicolumn{5}{|c|}{ Сироватка крові } \\
\hline $\begin{array}{l}\text { Остеокальцин, } \\
\text { нг/мл }\end{array}$ & $78,75 \pm 2,33$ & $\begin{array}{c}75,49 \pm 2,73 \\
\mathrm{p}_{1}>0,05\end{array}$ & $\begin{array}{c}96,13 \pm 2,80 \\
p_{1}<0,001 \\
p_{2}<0,001\end{array}$ & $\begin{array}{c}74,98 \pm 2,45 \\
p_{1}>0,05 \\
p_{3}>0,05 \\
p_{4}<0,001\end{array}$ \\
\hline $\begin{array}{l}\text { Лужна фосфатаза, } \\
\text { мкат/л }\end{array}$ & $14,92 \pm 0,24$ & $\begin{array}{c}11,13 \pm 0,25 \\
\mathrm{p}_{1}<0,001\end{array}$ & $\begin{array}{c}13,68 \pm 0,27 \\
\mathrm{P}_{1}<0,01 \\
\mathrm{P}_{2}<0,001\end{array}$ & $\begin{array}{c}11,48 \pm 0,33 \\
P_{1}<0,001 \\
P_{3}>0,05 \\
P_{4}<0,001\end{array}$ \\
\hline $\begin{array}{l}\text { Кисла фосфатаза, } \\
\text { мкат/л }\end{array}$ & $3,82 \pm 0,14$ & $\begin{array}{c}4,52 \pm 0,16 \\
\mathrm{P}_{1}<0,01\end{array}$ & $\begin{array}{l}5,67 \pm 0,22 \\
p_{1}<0,001 \\
p_{2}<0,002\end{array}$ & $\begin{array}{l}3,57 \pm 0,19 \\
\mathrm{P}_{1}>0,05 \\
\mathrm{P}_{3}<0,01 \\
\mathrm{P}_{4}<0,001\end{array}$ \\
\hline $\begin{array}{l}\text { Мінералізуючий } \\
\text { індекс (ЛФ/КФ) }\end{array}$ & $3,95 \pm 0,12$ & $\begin{array}{l}2,52 \pm 0,13 \\
\mathrm{P}_{1}<0,001\end{array}$ & $\begin{array}{c}2,45 \pm 0,11 \\
p_{1}<0,001 \\
p_{2}>0,05\end{array}$ & $\begin{array}{c}3,34 \pm 0,24 \\
\mathrm{P}_{1}<0,05 \\
\mathrm{P}_{3}<0,02 \\
\mathrm{P}_{4}<0,01 \\
\end{array}$ \\
\hline \multicolumn{5}{|c|}{ Супернатант гомогенату тканин пародонта } \\
\hline $\begin{array}{l}\text { Остеокальцин, } \\
\text { нг/мг }\end{array}$ & $30,97 \pm 1,36$ & $\begin{array}{c}38,54 \pm 2,01 \\
p_{1}<0,01\end{array}$ & $\begin{array}{c}77,80 \pm 2,29 \\
\mathrm{P}_{1}<0,001 \\
\mathrm{P}_{2}<0,001\end{array}$ & $\begin{array}{c}46,42 \pm 2,85 \\
P_{1}<0,001 \\
P_{3}<0,05 \\
P_{4}<0,001\end{array}$ \\
\hline $\begin{array}{l}\text { Лужна фосфатаза, } \\
\text { мкат/кг }\end{array}$ & $4,65 \pm 0,16$ & $\begin{array}{l}8,07 \pm 0,20 \\
\mathrm{p}_{1}<0,001\end{array}$ & $\begin{array}{c}37,66 \pm 0,65 \\
P_{1}<0,001 \\
P_{2}<0,001\end{array}$ & $\begin{array}{c}15,70 \pm 0,35 \\
\mathrm{p}_{1}<0,001 \\
\mathrm{P}_{3}<0,001 \\
\mathrm{P}_{4}<0,001 \\
\end{array}$ \\
\hline $\begin{array}{l}\text { Кисла фосфатаза, } \\
\text { мкат/кг }\end{array}$ & $2,13 \pm 0,07$ & $\begin{array}{l}2,86 \pm 0,12 \\
p_{1}<0,001\end{array}$ & $\begin{array}{l}4,88 \pm 0,15 \\
\mathrm{p}_{1}<0,001 \\
\mathrm{p}_{2}<0,001\end{array}$ & $\begin{array}{l}2,43 \pm 0,11 \\
\mathrm{P}_{1}<0,05 \\
\mathrm{P}_{3}<0,05 \\
\mathrm{P}_{4}<0,001\end{array}$ \\
\hline $\begin{array}{l}\text { Мінералізуючий } \\
\text { індекс (ЛФ/КФ) }\end{array}$ & $2,21 \pm 0,11$ & $\begin{array}{c}2,88 \pm 0,16 \\
p_{1}<0,01\end{array}$ & $\begin{array}{l}7,77 \pm 0,17 \\
\mathrm{p}_{1}<0,001 \\
\mathrm{P}_{2}<0,001\end{array}$ & $\begin{array}{c}6,63 \pm 0,39 \\
\mathrm{p}_{1}<0,001 \\
\mathrm{P}_{3}<0,001 \\
\mathrm{p}_{4}<0,05\end{array}$ \\
\hline
\end{tabular}

Примітки:

1. $\mathrm{p}_{1}$ - вірогідність відмінностей між контрольною групою і експериментальними групами;

2. р $_{2}$ - вірогідність відмінностей між групою з пародонтитом і групою з пародонтитом на тлі гіпертиреозу;

3. $\mathrm{p}_{3}$ - вірогідність відмінностей між групою з пародонтитом і групою з пародонтитом на тлі гіпотиреозу;

4. $\mathrm{p}_{4}$ - вірогідність відмінностей між групою з пародонтитом на тлі гіпертиреозу і групою з пародонтитом на тлі гіпотиреозу.

Остеокальцин - це кальційзв'язуючий білок кісткової тканини з невеликою молекулярною масою (5.4 kDa), вміст якого становить 10-20 \% від усіх неколагенових білків кісткового матриксу [19]. Остеокальцин синтезується зрілими остеобластами, остеоцитами та одонтобластами та вважається найпоширенішим неколагеновим білком кісткового матриксу, що специфічний для кісткової тканини та дентину. Його розглядають як один з найінформативніших біохімічних маркерів формування кісткової тканини та швидкості «кісткового обороту» [21]. Циркулюючий в крові остеокальцин - результат синтезу de novo, а не вивільнений при резорбції кісткової тканини, тому за його рівнем можна оцінити метаболічну активність остеобластів [22].

Ми встановили, що у тварин зі змодельованим пародонтитом вміст остеокальцину у сироватці крові достовірно не змінився, а у гомогенаті тканин пародонта зріс на 24,4\% $(p<0,01)$ відносно контрольної групи тварин (табл. 2). У тварин 3 пародонтитом на фоні гіпертиреоїдизму вміст остеокальцину у сироватці крові достовірно збільшився на $22 \%$, а у гомогенаті тканин паро- 
Огляди літератури, оригінальні дослідження, погляд на проблему

донта - у 2,5 раза $(p<0,001)$. У щурів з пародонтитом на фоні гіпотиреоїдизму вміст остеокальцину у сироватці крові достовірно не змінився відносно контрольної групи тварин, а у супернатанті гомогенату тканин пародонта - збільшився на $49,9 \%(p<0,001)$.

Мельник Н. С. та Мельник А. С. обстежили 192 хворих на генералізований хронічний пародонтит із дисфункцією щитоподібної залози. Показники рівня остеокальцину у сироватці крові в контрольній групі (генералізований пародонтит) були в межах норми. Рівень остеокальцину в І групі (супутній гіпертиреоз) у хворих на генералізований пародонтит був незначно підвищений. У хворих II групи (супутній гіпотиреоз) із генералізованим пародонтитом рівень остеокальцину був знижений [23].

Неодноспрямовані зміни активності лужної фосфатази і вмісту остеокальцину у нашому дослідженні можна пояснити тим, що ці два показники не відображають ідентичні аспекти кісткоутворення [24]. Що стосується змін концентрації остеокальцину у зубоясенній рідині за умов пародонтиту, то дані літератури $\epsilon$ суперечливими. Так, K. Kunimatsu та співавтори не визначили підвищення рівня остеокальцину у зубоясенній рідині пацієнтів з гінгівітом, проте встановили позитивні кореляційні зв'язки між концентрацією остеокальцину у зубоясенній рідині і клінічними параметрами у пацієнтів з пародонтитом [25] A. J. Lee та співавтори продемонстрували аналогічні рівні остеокальцину у зубоясенній рідині на уражених і

\section{ЛІТЕРАТУРА}

1. Аналіз оперативних втручань при патології щитоподібної залози в Чернівецькій області / В. В. Білоокий, Н. П. Ткачук, М.І.Шеремет, Я. В. Гирла // Буковинський медичний вісник. - 2014. - Т. 18, № 3 (71). С. $172-174$.

2. Бабак О. Я. Вплив тиреоїдної дисфункції на перебіг артеріальної гіпертензії у хворих на неалкогольну жирову хворобу печінки / О. Я. Бабак, С. М. Тельнова // Сучасна гастроентерологія. -2015. - № 2 (82). - С. 97-102.

3. Хронический генерализованный пародонтит у больных эндемическим зобом / Т. Р. Сутаева, С. Р. Минкаилова, И. М. Шамов, О. Г. Омаров // Вестник новых медицинских технологий. - 2012. - Т. ХІХ, № 3. - С. 46-47.

4. Деньга О. В. Роль тиреоидных гормонов в интегральной регуляции костного метаболизма в норме и при гипотиреозе / О. В. Деньга, К. А. Колесник // Таврический медико-биологический вестник. - 2012. - Т. 15, №1 (57). - С. 332-337.

5. The skeletal consequences ofthyrotoxicosis / J. Nicholls, M. Brassil, G. Williams, J. Bassett // J. Endocrinol. - 2012. - No. 213. - P. 209-211.

6. Gorka J. Metabolic and clinical consequences of hyperthyroidism on bone density / J. Gorka, R. Taylor-Gjevre, T. Arnason // Int. J. Endocrinol. - 2013. - P. 638727. здорових ділянках у пацієнтів з хронічним пародонтитом [26]. A. N. Wilson та співавторам не вдалося виявити остеокальцин у зубоясенній рідині пацієнтів із нелікованим пародонтитом [27] 3 іншого боку, Nakashima та співавтори [28] виявили підвищений рівень остеокальцину у зубоясенній рідині на ділянках з пародонтитом відносно неуражених ділянок та уражених гінгівітом. У дослідженні Sema Becerik та співавторів встановлено зниження рівня остеокальцину за умови пародонтиту відносно здорових пацієнтів. Більше того, рівень остеокальцину у зубоясенній рідині негативно корелював з клінічними параметрами у пацієнтів з пародонтитом [19]. Ці дані можуть вказувати на патологічний «кістковий оборот» за умови пародонтиту.

Висновки. Експериментальний пародонтит супроводжується порушеннями метаболізму кісткової тканини за рахунок підвищення як процесів резорбції, так і процесів кісткоутворення. Пародонтит на тлі гіпертиреозу характеризується більш вираженими порушеннями кісткового метаболізму за рахунок одночасного підвищення процесів резорбції та кісткоутворення. Пародонтит на тлі гіпотиреозу супроводжується гальмуванням процесів резорбції кісткової тканини та менш вираженим кісткоутворенням.

Перспективи подальших досліджень. Подальші дослідження мають бути спрямовані на дослідження мінерального дисбалансу за умови експериментального пародонтиту на тлі дисфункції щитоподібної залози.

7. Basset J. The skeletal phenotypes of TRa and TR $\beta$ mutant mice / J. Basset, G. Williams // J. Mol. Endocrinol. 2009. - No. 42. - P. 269-282.

8. Tuchendler $D$. The influence of thyroid dysfunction on bone metabolism / D. Tuchendler, M. Bolanowski // Thyroid Research. - 2014. - No. 7. - P. 12.

9. Effect of cyclical forces on the periodontal ligament and alveolar bone remodeling during orthodontic tooth movement / Z. Kalajzic, E. B. Peluso, A. Utreja [et al.] // Angle Orthod. - 2014. - No. 84. - P. 297-303.

10. Cardoso L. F. The multiple effects of thyroid disorders on bone and mineral metabolism / L. F. Cardoso, L. M. Z. Maciel, F. J. A. de Paula // Arq. Bras. Endocrinol. Metab. - 2014. - No. 58/5. - P. 452-463.

11. Состояние костного метаболизма при заболеваниях щитовидной железы (обзор) / И. Н. Пиксин, В. И. Давыдкин, А. С. Московченко [и др.] // Медицинский альманах. - 2016. - № 4 (44). - С. 154-157.

12. Dolidze N. M. Changes in intra- and extracellular $\mathrm{Ca}^{2+}$ concentration and prostaglandin E2 synthesis in osteoblasts of the femoral bone in experimental hyper- and hypothyroidism / N. M. Dolidze, D. D. Kezeli, L. O. Kilasoniya // Bull Exp. Biol. Med. - 2007. - No. 144. P. 17-20. 
13. Weak evidence of thyrotropin receptors in primary cultures of human osteoblast-like cells / J. Tsai, A. Janson, E. Bucht [et al.] // Calcif Tissue Int. - 2004. - No. 74. P. 486-491.

14. Моисеева Е. Г. Метаболический гомеостаз и имунная реактивность организма в динамике воспаления в тканях пародонта (экспериментальное исследование) : автореф. дис. на соискание ученой степени доктора мед. наук : спец. 14.00.16 «Патологическая физиология" / Е. Г. Моисеева. - М., 2008. - 45 с.

15. Ратушненко В. О. Функціональна роль тіол-дисульфідної системи при експериментальному гіпо- і гіпертиреозі / В. О. Ратушненко // Одеський медичний журнал. - 2010. - № 2 (118). - С. 17-20.

16. European convention for the protection of vertebrate animals used for experimental and other scientific purposes. - Council of Europe. Strasbourg. - 1986. No. 123. - P. 52.

17. Авдєєв О. В. Ступінь активності фосфатаз при експериментальному пародонтиті та за його корекції / О. В. Авдєєв // Клінічна стоматологія. - 2013. - № 3-4. C. 13-17.

18. Экспериментальные методы исследования стимуляторов остеогенеза : метод. рекомендации / А. П. Левицкий, О. А. Макаренко, О.В.Деньга [та ін.]. К. : ГФЦ, 2005. - 30 c.

19. Gingival crevicular fluid calprotectin, osteocalcin and cross-linked N-terminal telopeptid levels in health and different periodontal diseases / S. Becerik, B. Afacan, V. Ö. Oztürk [et al.] // Disease Markers. - 2011. - No. 31. P. 343-352.

20. Николаева А. В. Изучение степени деструктивных изменений в тканях пародонта при моделировании пародонтита у белых крыс - самок различных возрастных периодов / А. В. Николаева, О. А. Макаренко // Клінічна та експериментальна патологія. - 2016. - Т. XV, № 4 (58). - C 74-78.

\section{REFERENCES}

1. Bilookyi, V.V., Tkachuk, N.P., Sheremet, M.I., Hyrla, la.V. (2014). Analiz operatyvnykh vtruchan pry patolohii shchytopodibnoi zalozy v Chernivetskii oblasti [Analysis of surgical interventions in pathology of thyroid gland in Chernivtsi region]. Bukovynskyi medychnyi visnyk - Bukovyna Medical Journal, 18, 3 (71), 172-174 [in Ukrainian].

2. Babak, O.la., \& Telnova, S.M. (2015). Vplyv tyreoidnoi dysfunktsii na perebih arterialnoi hipertenzii u khvorykh na nealkoholnu zhyrovu khvorobu pechinky [Influence of thyroid dysfunction on the course of arterial hypertension in patients with nonalcoholic fatty liver disease]. Suchasna hastroenterolohiia - Modern Gastroenterology, 2 (82), 97102 [in Ukrainian].

3. Sutaeva, T.R., Minkailova, S.R., Shamov, I.M., \& Omarov, O.G. (2012). Khronicheskiy generalizovannyy parodontit u bolnykh endemicheskim zobom [Chronic generalized periodontitis in patients with endemic goiter]. Vestnik novykh meditsinskkh tekhnologiy - Journal of New Medical Technologies, XIX, 3, 46-47 [in Russian].

4. Denga, O.V., \& Kolesnik, K.A. (2012). Rol tireoidnykh gormonov $v$ integralnoy regulyatsii kostnogo metabolizma v norme i pri gipotireoze [The role of thyroid hormones in the integrated regulation of bone metabolism in normal
21. Дрок В. О. Визначення показників метаболізму кісткової тканини у пацієнтів з зубощелепними аномаліями та остеопенічним синдромом / В. О. Дрок // Вісник проблем біології і медицини. - 2015. - Вип. 2., Т. 2 (119). - С. 79-82.

22. Галкина О. П. Уровень маркеров костного метаболизма у подростков с генерализованным пародонтитом, на фоне деформаций позвоночника / О. П. Галкина // Вісник стоматології. - 2013. - № 3. - С. 30-33.

23. Мельник Н. С. Маркери ремоделювання кісткової тканини у хворих на генералізований пародонтит із супутнім гіпо- і гіпертиреозом / Н. С. Мельник, A. С. Мельник // TEMPUS: електронне наукове фахове видання. - Електронні дані. - [Запоріжжя : ЗДМУ]. С. 109-110. - Режим доступу: http://dspace.zsmu.edu. ua/bitstream/123456789/3842/1/15_lyst_TEMPUS_\%D0 \%97\%D0\%94\%D0\%9C\%D0\%A3_109-110.pdf (дата звернення 23.11.2017 р.). - Назва з екрана.

24. Serum osteocalcin levels and bone alkaline phosphatase isoenzyme after oophorectomy and in primary hyperthyroidism / J. Stepan, J. Presi, P. Broulik, V. Pacovsky // J. Clin. Endocrinol. Metab. - 1987. - No. 64. - P. 1079-1082.

25. A cross-sectional study on osteocalcin levels in gingival crevicular fluid from periodontal patients / K. Kunimatsu, S. Mataki, H. Tanaka [et al.] // J. Periodontol. -1993. No. 64. - P. 865-869.

26. Gingival crevicular fluid osteocalcin in adult periodontitis / A. J. Lee, T. F. Walsh, S. J. Hodges, A. Rawlinson // J. Clin. Periodontol. - 1999. - No. 26. - P. 252-256.

27. Bone turnover markers in serum and periodontal microenvironments / A. N. Wilson, M. J. Schmid, D. B. Marx, R. A. Reinhardt // J. Periodont. Res. - 2003. - No. 38. P. 355-361.

28. Nakashima K. Osteocalcin, prostaglandin E2 and alkaline phosphatase in gingival crevicular fluid: Their relations to periodontal status / K. Nakashima, N. Roehrich, G. Cimasoni // J. Clin. Periodontol. - 1994. - No. 21. - P. 327-333.

and hypothyroidism]. Tavricheskiy mediko-biologicheskiy vestnik - Tavrichesky Medico-biological Journal, 15, 1 (57), 332-337 [in Russian].

5. Nicholls, J., Brassil, M., Williams, G., \& Bassett, J. (2012). The skeletal consequences ofthyrotoxicosis. J. Endocrinol., 213, 209-211.

6. Gorka, J., Taylor-Gjevre, R., \& Arnason, T. (2013). Metabolic and clinical consequences of hyperthyroidism on bone density. Int. J. Endocrinol., 638727.

7. Basset, J., \& Williams, G. (2009). The skeletal phenotypes of TRa and TRß mutant mice. J. Mol. Endocrinol., $42,269-282$.

8. Tuchendler, D., \& Bolanowski, M. (2014). The influence of thyroid dysfunction on bone metabolism. Thyroid Research, 7, 12

9. Kalajzic, Z., Peluso, E.B., Utreja, A., Dyment, N., Nihara, J., Xu, M. et al. (2014). Effect of cyclical forces on the periodontal ligament and alveolar bone remodeling during orthodontic tooth movement. Angle Orthod., 84, 297-303.

10. Cardoso, L.F., Maciel, L.M.Z., \& de Paula F.J.A. (2014). The multiple effects of thyroid disorders on bone and mineral metabolism. Arq. Bras. Endocrinol. Metab., $58 / 5,452-463$. 
Огляди літератури, оригінальні дослідження, погляд на проблему

11. Piksin, I.N., Davyidkin, V.I. Moskovchenko, A.S. Vilkov, A.V. \& Kechaykin, A.N. (2016). Sostoyanie kostnogo metabolizma pri zabolevaniyakh shchitovidnoy zhelezy [The state of bone metabolism in diseases of the thyroid gland]. Meditsinskiy almanakh - Medical Almanac, 4 (44), 154-157 [in Russian].

12. Dolidze, N.M., Kezeli, D.D., \& Kilasoniya, L.O. (2007). Changes in intra- and extracellular Ca2+ concentration and prostaglandin E2 synthesis in osteoblasts of the femoral bone in experimental hyper- and hypothyroidism. Bull. Exp. Biol. Med., 144, 17-20.

13. Tsai, J., Janson, A., Bucht, E., Kindmark, H., Marcus, C., Stark, A. et al. (2004). Weak evidence of thyrotropin receptors in primary cultures of human osteoblast-like cells. Calcif. Tissue Int., 74, 486-491.

14. Moyseeva, E.H. (2008). Metabolicheskiy gomeostaz i imunnaya reaktivnost organizma $v$ dinamike vospaleniya $v$ tkanyakh parodonta [Metabolic homeostasis and immune reactivity of the organism in the dynamics of inflammation in periodontal tissues]. Extended abstract of Doctor's thesis. Moscow [in Russian].

15. Ratushnenko, V.O. (2010). Funktsionalna rol tiol-dysulfidnoi systemy pry eksperymentalnomu hipo- i hipertyreozi [Functional role of thiol-disulphide system in experimental hypo- and hyperthyroidism]. Odeskyi medychnyi zhurnal - Odesa Medical Journal, 2 (118), 17-20 [in Ukrainian].

16. European convention for the protection of vertebrate animals used for experimental and other scientific purposes. (1986). Council of Europe. Strasbourg, 123, 52.

17. Avdieiev, O.V. (2013). Stupin aktyvnosti fosfataz pry eksperymentalnomu parodontyti ta za yoho korektsii [Stupin activity of phosphatases during experimental parodontitis and after correction]. Klinichna stomatolohiia Clinical Stomatology, 3-4, 13-17 [in Ukrainian].

18. Levitskiy, A.P., Makarenko, O.A., \& Denga, O.V. (2005). Eksperimentalnyye metody issledovaniya stimulyatorov osteogeneza [Experimental methods of research of stimulants of osteogenesis]. Kyiv: GFTs [in Russian].

19. Becerik, S., Afacan, B., \& Oztürk, V.Ö. (2011). Gingival crevicular fluid calprotectin, osteocalcin and crosslinked N-terminal telopeptid levels in health and different periodontal diseases. Disease Markers, 31, 343-352.

20. Nikolaeva, A.V., \& Makarenko, O.A. (2016). Izuchenie stepeni destruktivnykh izmeneniy $v$ tkanyah parodonta pri modelirovanii parodontita u belykh krys - samok razlichnykh vozrastnykh periodov [The study of the degree of destructive changes in periodontal tissues during the modeling of periodontitis in white rats - females of different age periods]. Klinichna ta eksperimentalna patologiia - Clinical and Experimental Pathology, XV, 4 (58), 74-78 [in Russian].

21. Drok, V.O. (2015). Vyznachennia pokaznykiv metabolizmu kistkovoi tkanyny u patsiientiv z zuboshchelepnymy anomaliiamy ta osteopenichnym syndromom [Determination of bone metabolism in patients with dental anomalies and osteopenic syndrome]. Visnyk problem biolohii i medytsyny - Journal of Biology and Medicine, 2, 2 (119), 79-82 [in Ukrainian].

22. Galkina, O.P. (2013). Uroven markerov kostnogo metabolizma u podrostkov s generalizovannym parodontitom, na fone deformatsiy pozvonochnika [The level of markers of bone metabolism in adolescents with generalized periodontitis, against the backdrop of deformities of the spine]. Visnyk stomatolohii - Journal of Dentistry, 3, 30-33 [in Russian].

23. Melnyk, N.S., \& Melnyk, A.S. Markery remodeliuvannia kistkovoi tkanyny u khvorykh na heneralizovanyi parodontyt iz suputnim hipo- i hipertyreozom [Markers of bone remodeling in patients with generalized periodontitis with concomitant hypo- and hyperthyroidism]. TEMPUS. dspace.zsmu.edu.ua. Retrieved from: http://dspace. zsmu.edu.ua/bitstream/123456789/3842/1/15_lyst_TEMP US_\%D0\%97\%D0\%94\%D0\%9C\%D0\%A3_109-110.pdf [in Ukrainian]

24. Stepan, J., Presi, J., Broulik, \& P., Pacovsky, V. (1987). Serum osteocalcin levels and bone alkaline phosphatase isoenzyme after oophorectomy and in primary hyperthyroidism. J. Clin. Endocrinol. Metab., 64, 1079-1082.

25. Kunimatsu, K., Mataki, S., Tanaka, H., Mine, N., Kiyoki, M., Hosoda, K. et al. (1993). A cross-sectional study on osteocalcin levels in gingival crevicular fluid from periodontal patients. J. Periodontol., 64, 865-869.

26. Lee, A.J., Walsh, T.F., Hodges S.J., Rawlinson, A. (1999). Gingival crevicular fluid osteocalcin in adult periodontitis. J. Clin. Periodontol, 26, 252-256.

27. Wilson, A.N., Schmid, M.J., Marx, D.B., \& Reinhardt, R.A. (2003). Bone turnover markers in serum and periodontal microenvironments. J. Periodont. Res., 38, 355-361.

28. Nakashima, K., Roehrich, N., \& Cimasoni, G. (1994). Osteocalcin, prostaglandin E2 and alkaline phosphatase in gingival crevicular fluid: Their relations to periodontal status. J. Clin. Periodontol., 21, 327-333.

\section{ПОКАЗАТЕЛИ КОСТНОГО МЕТАБОЛИЗМА У КРЫС С ПАРОДОНТИТОМ НА ФОНЕ ГИПЕР- И ГИПОТИРЕОЗА}

\section{๑В. В. Щерба, И. Я. Криницкая, В. Р. Мачоган, М. М. Корда}

ГВУз «Тернопольский государственный медицинский университет имени И. Я. Горбачевского МЗ Украины»

РЕЗЮМЕ. В Украине за последние пять лет количество больных с дисфункцией щитовидной железы увеличилась в 5 раз. Изменения деятельности щитовидной железы неизбежно сказываются на различных системах организма, в том числе и на функции и морфологии органов и тканей полости рта.

Целью исследования было изучить показатели костного метаболизма у крыс с пародонтитом без сопутствующей патологии и на фоне гипер- и гипотиреоза. 
Огляди літератури, оригінальні дослідження, погляд на проблему

Материал и методы. Опыты проведены на 48 беспородных половозрелых белых крысах-самцах, которые были поделены на четыре группы: контрольная, группа с пародонтитом, группа с пародонтитом на фоне гипертиреоза, группа с пародонтитом на фоне гипотиреоза.

Результаты. Экспериментальный пародонтит сопровождается нарушениями метаболизма костной ткани за счет повышения как процессов резорбции, так и процессов костеобразования. Пародонтит на фоне гипертиреоза характеризуется более выраженными нарушения костного метаболизма за счет одновременного повышения процессов резорбции и костеобразования. Пародонтит на фоне гипотиреоза сопровождается торможением процессов резорбции костной ткани и менее выраженным костеобразованием.

КЛЮЧЕВЫЕ СЛОВА: пародонтит; тиреоидные гормоны; костный метаболизм.

\section{THE INDICES OF BONE METABOLISM IN RATS WITH PERIODONTITIS ON THE BACKGROUND OF HYPER- AND HYPOTHYROIDISM}

\section{○V. V. Shcherba, I. Ya. Krynytska, V. R. Machohan, M. M. Korda}

\section{Horbachevsky Ternopil State Medical University}

SUMMARY. In Ukraine over the past five years, the number of patients with thyroid dysfunction increased five-fold. Changes in the activity of the thyroid gland inevitably affect the various systems of the body, including the functions and morphology of the organs and tissues of the oral cavity.

The aim of the study - to learn the indicators of bone metabolism in rats with periodontitis without concomitant pathology and on the background of hyper- and hypothyroidism.

Materials and Methods. The experiments were carried out on 48 outbred mature male white rats, which were divided into four groups: the control group, the group with periodontitis, the group with periodontitis combined with hyperthyroidism, the group with periodontitis combined with hypothyroidism.

Results. Experimental periodontitis is accompanied by impaired metabolism of bone tissue due to an increase in both the processes of resorption and bone formation processes. Periodontitis with hyperthyroidism is characterized by more pronounced disturbances in bone metabolism due to a simultaneous increase in the processes of resorption and bone formation. Periodontitis on the background of hypothyroidism is accompanied by inhibition of bone resorption processes and less pronounced bone formation.

KEY WORDS: periodontitis; thyroid hormones; bone metabolism. 